
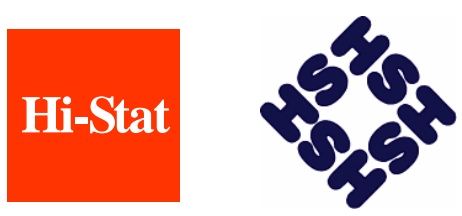

Discussion Paper Series

No.14

Firm level analysis of information network use and productivity in Japan

Kazuyuki Motohashi

February 2004

Hitotsubashi University Research Unit for Statistical Analysis in Social Sciences A 21st-Century COE Program

Institute of Economic Research Hitotsubashi University Kunitachi, Tokyo, 186-8603 Japan http://hi-stat.ier.hit-u.ac.jp/ 


\title{
Firm level analysis of information network use and productivity in Japan
}

\author{
by
}

\author{
Kazuyuki Motohashi
}

Institute of Innovation Research, HItotsubashi University and RIETI

\begin{abstract}
This paper shows firm level micro analysis of information network use and its impact on firm's productivity. New evidences on economic impacts of IT by type of its application are provided, based on METI's firm level data of Japanese manufacturers and distributors. It is found that productivity impact of information network use is different, depending on application of network. In addition, due to rapid progress of information technology, economic implications of information network are different also by the timing of its introduction. METI's datasets covers information on network use by its type, as well as firm's IT use throughout the period of 1990's. Detail analysis of information network use at Japanese firms can shed a new light on heterogeneous and dynamic nature of firm level IT use and its performance.
\end{abstract}

JEL code: D24, O33

This paper was presented at Comparative Analysis of Enterprise (Firm) Data (CAED) Conference, 15-16, September 2003 in London. Author would like to thank participants for their helpful comments. It is also acknowledged that METI kindly supplied micro-data of Basic Survey of Business Structure and Activity. Views expressed in this paper are author's and not those of his organizations. 


\section{Introduction}

Is information economy a driving force of recent productivity upward shift, observed in the United States and other counties? None can deny that dramatic technological progress is observed in IT, which drives down quality adjusted computer price at the rate of more than $10 \%$ annually. In addition, we cannot imagine our today's day life without Internet, which started to be commonly used in the middle 1990's. This timing coincides with a kinked point of US labor productivity trend, i.e., after productivity slow-down in 1980's, called Solow's productivity paradox, US labor productivity trend has regained its speed in the late 1990's. Oliner and Sichel (2000) show that about two thirds of $1.5 \%$ productivity revival after 1995 can be attributed to the growth in IT investment. On the other hand, Gordon (2000) argues that recent US labor productivity growth is not structural shift but mere procyclical movement and that productivity growth is observed only in IT sectors, and IT user sectors cannot take advantage of benefit from IT investment. After the burst of "IT bubble", the US economic growth rate slowed down, and some skeptical views on "New Economy" is prevailing. However, US labor productivity by BLS shows strong performance even after IT bubble burst, and it is fair to say IT investment surge can explain not all but significant portion of US productivity revival after the middle 1990's. (Bailiy (2002))

In contrast, the Japanese economy of the 1990's was mired in unfavorable conditions following the collapse of the bubble economy in early 1990's. Japan's GDP growth rate averaged $1.4 \%$ in 1990 's, in contrast to $4 / 1 \%$ in 1980 's. There is a puzzle about this sluggish economy situation in Japan in the era of new economy, since it is found that Japanese firms also heavily invested in information technology. Jorgenson and Motohashi (2003) conducts growth accounting exercise to compare the role of IT in economic growth between two countries, and finds that the contribution of IT capital services to economic growth in Japan's late 90's has about the same size as that in the US. In addition, it is found that in Japan, TFP grows more rapidly in the second half of 1990's than the first half. As a result, a slow pace of Japanese economic growth comes mainly from negative contribution of labor inputs to GDP growth. 
Growth accounting exercise is useful to have a global view on the relationship between IT investments and economic growth. However it shows only a snap shot of what have happened. Behind aggregated figures in growth accounting exercise, productivity and IT investment dynamics does exist at firm level. This paper analyzes the effect of IT investments and network use on firm level performance, particularly focusing on productivity. At first, this paper provides firm level evidence on the positive relationship between use of IT and productivity growth. In order to understand this relationship properly, it is important to control for firm level unobserved factors explaining productivity growth. In addition, since there must be reverse causality of IT and firm performance, i.e., a good firm invests in IT more, a great care should be taken in the timing of IT investment and performance.

In addition, a rich firm level dataset for IT and performance by METI allows us to investigate the nature of general purpose technology of IT and its economic consequences. It is found that IT is not a sector specific technology, but it diffuses widely across industry. (Motohashi (1997)) The other side of coin of generality in use is the variety of its application. For example, flexible manufacturing system and internet banking is totally different kind of application of IT. Even within a firm, various IT applications from financial accounting system to inventory control system can be found. The METI's firm level dataset include information on use of information network by type of application, and comparing economic impact by type of IT application provides useful information to understand the relationship between IT and firm level performance.

A related issue to be addressed for better understanding of business use of IT is firm's is user side innovation, mainly paralleled with changes in firm's organization. In a case of introduction of flexible manufacturing system at a factory, it is not difficult to imagine significant change in work style is needed. In addition, there may need some training for new equipment, and new incentive system should be introduced. At the firm level, IT investment is not simply the process of just buying computers and software. Successful introduction of IT system requires co-invention by suppliers and users, including organizational innovation. (Bresnahan and Greenstein (1997)) In addition, it is found that a firm, which does not achieve the expected payoffs from IT investments, does not have an appropriate organizational and human resource strategy (Bresnahan et. al. 
(2002)). This paper touches on this issue as well.

The next section of this paper is devoted to description of data for IT and business performance, called (BSBSA) ${ }^{1}$. METI's BSBSA asks information network use by the type of its application, organizational characteristics such as supplier and customer relationship and business performance variables. In this study, panel data of 1991 and every year from 1994 to 2000 are used. Analysis of the relationship between IT and firm performance, particularly focusing on productivity, is provided in the following section. Then, further look at business use of IT by using information network variables is conducted. Finally, this paper concludes with policy implications and future research agenda.

\section{Data}

In Japan, METI has a census survey for all firms in manufacturing, wholesale and retail trade and some business service sectors with more than 50 employees and 30 million yen capital amount. It covers various kinds of items on firm's structure and activities, such as R\&D, overseas production, outsourcing and use of IT. Since it also provides financial statement information, such firm's activity variables can be interacted with firm's performance measurement such as productivity. This survey has started in 1991, and after 1994, it has been conducted annually, and the latest data available are ones in 2000. There are around 25,000 samples in each year, which allows us to construct panel data of about 14,000 firms from 1991 to $2000 .^{2}$

In this survey, IT expenditure data are available, instead of IT investment. IT expenditure is broadly defined, including rental or lease fees of computers, software investment, expense on information services and communication charges. As compare to IT capital stock, often used as IT input variables in econometric studies, the upside of IT expenditure is including software as well. In addition, the value of leased or rent computers is greater than that of purchased ones (Table 1). Therefore, this IT expenditure variable can capture firm's activity in IT investment more accurately than IT capital stock estimated by only using purchased computer investment data.

\footnotetext{
${ }^{1}$ Aggregate results are reported by MITI (1994).

${ }^{2}$ Motohashi (2001) provides details on panel data construction by METI's BSBSA.
} 
(Table 1)

In addition, IT network use variables are available in BSBSA, but only in years of 1991, 1994, 1997 and 2000. For 1991 and 1994, the use of information network was surveyed by intra firm or inter firm network, and by type of application such as inventory control, logistics management and customer relationship. In 1997, use of information network by intra firm and inter firm were surveyed, but not for IT use by type of application. Instead, other items such as use of EDI, CAD/CAM, EC etc. and the number of PCs per workers were surveyed. In 2000, survey items was modified again, and focused on collecting data about e-commerce activities, as well as use of intra firm and inter firm network.

BSBSA serves not only as a firm level census survey, but also as a lynchpin of METI's firm level survey. Another data source on ICT is METI's ICT Workplace Survey, and it can be combined with BSBSA by using BSBSA's firm code. Although linked data of BSBSA and ICT Workplace Survey gives a lot detailed variables, particularly on type of IT spending and network use, the number of observations decreases substantially. ${ }^{3}$ Therefore, only IT variables available from BSBSA are used in this paper.

\section{IT and firm level performance}

(1) IT and productivity analysis

\footnotetext{
${ }^{3}$ ICT Workplace Survey is an annual firm level survey for about 9,500 computer users in Japan. The survey items cover everything from conditions of the costs of information processing of different types, such as hardware, software, and information processing services, penetration of computers for workplace, and conditions of use of information processing networks, etc. As part of the plan to augment IT statistics in Japan, this survey was expanded and the 2001 version includes new survey items on e-commerce and ebusiness processes. The survey for e-commerce is conducted, by using both "broad" and "narrow" definitions of e-commerce by OECD. Data on the uses of e-commerce for each category of B2B buying and selling, and $\mathrm{B} 2 \mathrm{C}$ are collected by the type of e-business process. ICT Workplace Survey provides more detailed and up-to-date information on firm level IT related activities than BSBSA. However, since significant changes in sampling framework for the 2000 survey have been implemented, the construction of panel data is difficult. The number of observations in the 2000 survey is around 5,000, but linkage with the previous year gives only 1,000 or less observations. When it is linked with BSBSA panel data from 1994 to 1999 , the number of linked firm becomes nearly 3,000.
} 
A Number of researchers have tried to solve 'Solow's Paradox', based on the famous quip of Robert Solow, "You can see computer everywhere, except in productivity paradox." Brynjolfsson (1993) has compared more than 20 papers on this topic, and concluded that traditional tools of productivity measurement are still inadequate, and researcher must come up with better measurements, which take into account intangible utilities associated with IT investments. In this sense, empirical studies on IT and productivity show a history of searching for a good indicator of IT investment and econometric sophistication to investigate IT's impact on productivity.

Many studies on IT and productivity are conducted by means of production function to estimate the rate of return of IT investment. Morrison and Berndt (1991) and Berndt and Morrison (1995), based on industry-aggregate data, show that US manufacturing industries over-invest in IT capital products, while Lichtenberg (1993) and Brynjolfsson and Hitt (1995), based on firm level microdata, show that the marginal return of IT capital is significantly higher than that of other capital inputs. Such contradictory results between aggregate data and firm level data may be attributed to the firm level heterogeneity of IT. That is, firm level investigation into IT and productivity relationship picks up difference between 'good firm' and 'bad firm' in a sense of IT management, while such variation is slashed out in aggregate data.

In Japan, there are some studies on investigating IT and productivity relationship, but almost all of them are based on aggregated data, and an econometric work by using firm level data very rare. Motohashi (2001) is one of exceptions, which looks at the relationship of IT network use, firm's organization and productivity. However, since Motohashi (2001) uses a cross section data of BSBSA in 1991, it addresses only relative productivity impact of IT network use by its type of application, but not productivity impact of IT by comparing network users with non users due to the difficulty of controlling for firm level unobserved factors by cross section data.

In this paper, the following error component model of Cob Douglas production function is estimated first, using panel data.

$$
\begin{aligned}
& \ln V A_{i t}=\alpha \ln L_{i t}+\beta \ln K_{i t}+\gamma \ln I T_{i t}+u_{i t} \\
& u_{i t}=a_{i t}+e_{i t}+\varepsilon_{i t}
\end{aligned}
$$


where VA, L, K and IT is value added, non-IT labor input, non-IT capital input and IT input.

Error terms of equation (1) can be decomposed into $a_{i t}$ : firm specific unobservable factors for firm's performance, such as managerial capabilities and workers' motivation and $e_{i t}$ : exogenous shocks for firm's performance, such as macro economic business cycle, and $\varepsilon_{i t}$ :error terms associated with measurement errors. It is reasonable to assume that $a_{i t}=a_{i}$, which is time invariant for a short period. In addition, if we assume both $e_{i t}$ and $\varepsilon_{i t}$ are independent of right hand side variables, equation (1) can be treated as fixed effect model or random effect model, depending on assumption of the distribution of $a_{i}$.

The data from METI's BSBSA in 1991 and from 1994 to 2000 annually are used. The sample size is about 7,000 for manufacturing firms and about 4,500 for wholesale and retail ones, after firms with no IT expenditure are dropped from the whole samples. It should be noted that 'IT' in equation (1) does not indicate IT capital stock, but IT expenditure, deflated by proper price series. As is described in the previous section, IT expenditure data, including rental expense of IT hardware and software purchases reflect firm's IT stock more accurately than perpetual inventory stock data by using only purchased computer investments. IT expenditure data are deflated by IT stock rental service price series from Jorgenson and Motohashi (2003). In this paper, wages from IT related workers are also included in IT stock variable. Since BSBSA surveys the number of employees by type of occupation, IT labor service is estimated by the number of IT staffs times average wage for each firm. Consequently, the number of IT staffs is excluded in ' $L$ ' in equation (1), reflecting non-IT labor inputs. ' $\mathrm{K}$ ' in equation (1) comes from book value of capital stock, which includes IT capital stock from purchased computers. In this sense, decomposition of capital input into IT and non-IT cannot be done completely, and output elasticity of IT is estimated with under bias. However, as is mentioned before, since the share of purchased computer is small, this bias is supposed to be small. The value of capital stock is deflated by book value stock deflator ${ }^{4}$. Finally, the value added: VA is based on the normal concept of gross value added, but also

\footnotetext{
${ }^{4}$ The book value stock deflator is weighted average of historical investment goods deflator. The weight comes from geometric depreciation pattern of assets with 10 year service life.
} 
including IT expenditure, which is treated as an intermediate input in accounting convention. The amount of value added is deflated by 3 digit BSBSA industry classification output deflators. ${ }^{5}$

Table 2 shows estimation results of equation (1) by using data of 1991, 1994, 1997 and 2000. This table shows regression coefficients and t-values by pooled regression (TOTAL), cross section regression by data averaged over time (BETWEEN), fixed effect model regression (WITHIN) and random effect model regression (RANDOM). In all models, the coefficients with IT are positive with statistical significance at $1 \%$ level. Relatively larger coefficients for between dimensions of firms suggest the existence of unobserved factors of firm level performance, positively correlated with 'IT' variable. The result of Hausman test shows that there is statistically significant difference between fixed effect estimator and random effect estimator, which also supports unobserved factors' correlation with independent variables.

\section{(Table 2)}

Foregoing analysis focuses on firm level unobserved factors for performance, but it is also important to control for errors in variables in order to obtain consistent estimation of IT's contribution to value added. In case, there is a significant measurement errors in 'IT', its coefficient, $\gamma$, is biased downward, due to an attenuation effect of errors in variables. (Woodridge (2002)) Griliches and Hausman (1984) investigates this attenuation bias in a panel data model with unobserved variables, and shows that this bias is exacerbated by fixed effect estimation. In addition, it is found that bias becomes larger for the first difference model, as compared to the within regression model, and that in the first difference model, bias becomes larger as interval period becomes shorter.

Figure 1 shows IT output elasticities, $Y$ in equation (2), by various type of fixed effect estimators. ${ }^{6}$ All models are first difference models with two time periods, but the time interval and timing

\footnotetext{
${ }^{5}$ This deflator is constructed by Toshiyuki Matsuura, research staff at RIETI, based on Bank of Japan domestic corporate output price index. IT expenditure part is deflated by IT asset price series from Jorgenson and Motohashi (2003).

${ }^{6} \mathrm{Y}$ is statistical significant at $1 \%$ level in all models. All results of regressions will be provided, upon request.
} 
varies by model. For example, IT output elasticity of three year FE model shown in the timing between 1995 and 96 (about 0.09), is calculated by using data in 1994 and 1997. Comparing the size of elasticity by time interval in the same timing indicates whether there are attenuation biases in fixed effect model. For example, the output elasticity in 3 year FE model is, in general, larger than that in 1 year FE model for manufacturing firms, but by very small margins. In addition, such trend cannot be seen in wholesale and retail sector. Therefore, measurement errors in IT variables may not be so severe. ${ }^{7}$

(Figure 1)

A more important finding from Figure 1 is that output elasticity of IT varies by the timing significantly. For both manufacturing and wholesale \& retail sectors, it went down first and rebounded in 1996 or 97, then went up. Japanese economy had a small boom in 1995 and 96, then moved into recession from 1997. In contrast, aggregated IT expenditure increased even in 1996 and 1997. This macro economic shock causes biases with output elasticity of IT, particularly for 1 year interval FE models. In order to control for such macro economic shocks, it is appropriate to take longer estimation period. However, on the other hand, too long estimation period may be conflict with the assumption that unobservable factor is time invariant $\left(a_{i t}=a_{i}\right)$. Therefore, the following analysis of information network is conducted based on 3 year interval FE model.

(2) Information network use and productivity

It is confirmed that IT contributes to firm level value added growth in the previous section, but this only shows static association between IT and firm's performance. In this section, more detail analysis focusing on dynamic nature of IT, by using IT network use variable is provided. A picture of IT and firm level performance is not so simple to say good firms invest and no so good firms do not. There should be try and error process for successful introduction of IT. In addition, the timing of IT investment does matter as well due to rapid technological progress in information technology.

\footnotetext{
7 Attenuation bias can be observed more clearly in K.
} 
In BSBSA, network use variables are available in 1991, 94 and 97 data. The questionnaire is binary response one, for example, whether each kind of network is used. Table 3 shows the number of firms by use of information network in each of three periods. About half firms introduced any type of information network in all three periods. In contrast, about $5 \%$ of firms did not use it either of three periods. There are some firms, which gave up using networks, or newly applied them.

(Table3)

Table 4 shows the share of firms with each type of information network in 1991, 1994, 1997 and 2000. The share of network use does not change very much in general. For example, the share of intra firm network user is from $50 \%$ to $70 \%$ in all years. The share of inter firm network decreased significantly from 1994 to 1997 . However, this change is due to statistical reason. That is, the definition of inter firm network is changed and narrowed in 1997. In addition, due to rapid technological progress of IT, information network in 2000 must be totally different from that in 1991, even in the same category of statistical survey. Particularly, Internet, which starts to be used commercially in the middle 1990's, must change the specification of inter firm network significantly.

\section{(Table 4)}

In order to look at the impact of information network use by the timing of introduction on firm's performance, Figure 2 and Figure 3 shows the trend of labor productivity and employment for each category of firms, respectively. In order to control for industry effect, all data are demeaned, i.e., taking out industry mean in each data. Firstly, a firm with information network in recent period such as 1994 and 1997 shows relatively better performance in labor productivity and employment. Due to rapid technological progress of IT, the timing of introduction is an important factor to see IT's impact on firm's performance. Secondly, both ways of causality of better performance and network use can be found. Reverse causality, i.e., firm with good performance induced IT network use, can be found particularly in employment growth. Thirdly, a firm which once introduced network but gave it up in some period shows bad performance, particularly in 
employment growth. This suggests the existence of selection process of firm level IT use, in a sense that firms with complemental assets for better use of IT keep using IT, while the others gave it up.

(Figure 2) and (Figure 3)

(3) Productivity performance by type of information network

In this section, productivity impacts of IT are further investigated by using information of network use by type of its application. In 1991 and 1994, BSBSA surveys use of information network by 13 types of application, such as production and inventory control, logistics and human resource management. Motohashi (2001) shows productivity impacts of network use can be found more clearly in production operation type networks than in back office type ones, using cross section BSBSA data in 1991. This section extends this analysis by using panel data in 1991, 1994, 1997 and 2000.

The model used in this section is based on Cob Douglas production function shown in equation (1). In order to control for firm level unobservable factors, ai, we take first difference of equation (1). Then, productivity impact of information network use is tested in the following specification.

$$
\ln Y_{i}^{t} / Y_{i}^{t-1}=\alpha^{t} \ln L_{i}^{t} / L_{i}^{t-1}+\beta^{t} \ln K_{i}^{t} / K_{i}^{t-1}+\gamma^{t} \ln I T_{i}^{t} / I T_{i}^{t-1}+\delta^{t} \text { netuse }_{i}^{t-1}+\text { dummies }++\varepsilon_{i}^{t}
$$

Industry dummy variables are included in equation (2) by using BSBSA three digit industrial classification. Regression analysis is conducted by taking three-year interval for three periods, i.e., from 1991 to 94, from 1994 to 97 and from 1997 to 2000. For each year of 1991, 94 and 97, each type of information network use variable is included separately to compare its productivity impact.

Table 5 shows results of regression coefficients of network use variables. For example, a firm using intra firm network in 1991 has 1.0\% higher TFP growth rate from 1991 to 94 than a firm without using it. ${ }^{8}$ Firstly, most of coefficients are positive, while a few of them have a statistical

\footnotetext{
${ }^{8}$ Regression determines all coefficients to production factors. Therefore, a residuals left to network use variable
} 
significance at $10 \%$. Secondly, it seems that the positive impact of network use on TFP growth becomes greater for more recent period. In wholesale \& retail sector, much more positive coefficients with network use can be found in the periods from 1994 to 1997 and from 1997 to 2000 than in that from 1991 to 1994.

\section{(Table 5)}

In terms of the difference of impact by type of information network, great heterogeneity can be found in both cross section and time series dimensions. It is difficult to identify general rules. Motohashi (2001) shows that production operation type network such as production management and inventory control has greater impact on relative productivity than back office type network such as accounting and human resource management in 1991. However, the same type of conclusion cannot be drawn in a dimension of productivity growth.

Physical facility of information network, such as LAN facilities and Internet is common over type of network, but these can be used in different way, depending users' needs. This way of use at user-side is an important factor to determine user's performance from using IT. This is also related to the fitness of firm's complemental assets with use of information network. In addition, an evolutional process of introduction of information network can be observed in the previous section. Therefore, the variation of diffusion rate of various types of network may reflect outcomes from matching of a certain type of IT use and complemental assts fitted to this type of IT.

\section{Information network use and collaborative activities with other firms}

In this section, the role of complemental asset for effective use of information network use is analyzed by using variables on firm's collaborative production or R\&D activities with other firms in BSBSA data. There are various kinds of ways to capture the assets. A number of studies analyze the role of worker skills in effective use of IT. An introduction of IT system changes work at the organization in such a way that manipulating the system may need higher skills. This skill biased technical progress is supported by empirical studies for IT investment. For example, 
computer investments lead to a greater share of white collar workers with higher educational achievement, (Berndt and Morrison (1990), Berndt et. al. (1992)) and create more well-paid jobs. (Krueger (1993), Doms et. al. (1997)) Bresnahan (1997) departs from simple distinction of labor skills between while collars and blue collars and looks into detail into various types of skills in white collars.

Some studies address innovative work practices, such as work teams (e.g. quality circle), employee stock ownership and flexible job assignment. (Ichniowski et. al. (1996)) In most cases, an ad-hoc survey on work practice is conducted, and it has been found that "high performance work systems" lead to higher performance for firms. (Ichiniowski et. al. (1996)) Bresnahan et. al. (2002) shows that innovative work practices work well with information systems in a sense that improvement of communication efficiency by IT stimulates a worker's motivation in a decentralized decision making and incentive system. Brynjolffson et. al. (2002) addresses the value of intangible assets directly by looking at the relationship between innovative work practices and valuation of firms at stock market.

Complemental Assets of inter firm networks include firm's ability to handle relationship with suppliers and customers. SCM (supply chain management) and CRM (customer relationship management) are straightforward example for IT applications in this area. However, simply applying SCM system does not push up firm's performance. If so, Dell's effective SCM system could be imitated by other PC producers and Dell could loose its competitive edge instantly. There should be some firm specific intangible assets to explain excellent performance of Dell's SCM. Brynjolffson et. al. (1995) presents a model suggesting the number of supplier becomes smaller for firms using information network to deal with suppliers. Motohashi (2001) shows supportive evidence of this model by using 1991 BSBSA data.

Here, this point is further investigated by using variables on collaborative activities with other firms in BSBSA panel dataset. The following three kinds of variables are available; (1) use of outsourcing in production, (2) joint production with other firms and (3) joint R\&D with other firms and public research institutions. All variables are qualitative ones, i.e., whether a firm conducts each activity, and the following regression is conducted for each type of collaborative 
activities. Because these activities are supposed to be related with inter firm network use, we use inter firm network in all years of 1991, 94 and 97, production management network in 1991 and 94 and EDI in 1997 for NETUSE variables.

$$
\begin{aligned}
& \ln Y_{i}^{t} / Y_{i}^{t-1}=\alpha^{t} \ln L_{i}^{t} / L_{i}^{t-1}+\beta^{t} \ln K_{i}^{t} / K_{i}^{t-1}+\gamma^{t} \ln I T_{i}^{t} / I_{i}^{t-1}+\delta^{t} \text { netuse }_{i}^{t-1}+\phi^{t} \text { collab }_{i}^{t-1} \\
& +\varphi^{t} \text { netuse }_{i}^{t-1} \bullet^{t} \text { collab }_{i}^{t-1}+\text { dummies }+\varepsilon_{i}^{t}
\end{aligned}
$$

In this production function, netuse (use of information network) and collab (collaborative activity) and a cross term of those are included. In this model, if coefficient of cross term is positive, netuse and collab are complemental in terms of explaining TFP growth. Only manufacturing samples (about 7000 firms) are used in this analysis. Regression analysis is conducted in the period from 1991 to 1994, from 1994 to 1997 and from 1997 to 2000 separately, and results are shown in Table 6a, Table $6 \mathrm{~b}$ and Table $6 \mathrm{c}$, respectively.

(Table 6a-6c)

Firstly, in general, coefficients with interaction term are with positive sign, which suggests complementarity between network use and collaborative activities in terms of productivity impacts of them. However, only coefficient is at $1 \%$ statistical significance, production network and outsourcing in 1991. As is shown in the model (4) of lower panel of Table 6a, either only network use or only outsourcing does not help productivity growth, but both of them push up it, in this case. For the others, various kinds of pattern can be observed.

It is useful to compare productivity growth premium for firms with both network and collaboration with firms with either of them in Table 6a-6c. In general, it is higher for both groups than for either group. Careful look at the tables gives us an impression that co-production and co$\mathrm{R} \& \mathrm{D}$ have stronger power to explain complementarity with network use than outsourcing. Outsourcing of production may take various kinds of styles, such as subcontracting and OEM. In these types of outsourcing, specification of contract is presented by contractor, and it does not involve interactive communication and coordination. In contrast, co-production and co-R\&D are those activities, which should involve coordination activities, and those activities should be conducted more efficiently by using information network. 


\section{Conclusion}

In this paper, a firm level analysis of IT and productivity is conducted by using METI's BSBSA dataset. Macro level observation of IT's contribution to economic growth in Jorgenson and Motohashi (2003) is confirmed at the firm level. IT stock contributes to valued added growth significantly, and use of information network shows positive impacts on TFP growth, which further pushes up firm's output. It should be noted that IT's impacts on firm's output and productivity becomes greater in recent years. Commercial use of Internet started in the mid 90's. In addition, according to the information on revisions of semiconductor roadmap, acceleration of semiconductor's technological progress is observed in 1995. (Jorgenson (2001)) In addition to these findings of IT's progress, its wider diffusion may contribute to more efficient use of IT.

Dynamic process of firm's IT introduction and heterogeneity of performance impact by type of its application are also investigated. There are a great number of firms, which started and stopped using information network during a period of 1990's. It is found that a firm giving up using it performed badly as compared to those who keep using it. This finding suggests that IT does not save all firms, but for those, which have a good matching asset, positive impact of IT can been observed. It should be also noted that impact of network on productivity differs significantly by type of its application, by timing or by sector (manufacturing or wholesale \& retail trade), which suggest this complemental asset is heterogeneous in way of using IT.

Finally, we pick up firm's collaborative activities with others, as one of variables reflecting complemental asset, and test its complementarity with inter firm information network. It is observed a firm with both collaborative activities and inter firm network performs better than that with either of them. This pattern of complementarity is particularly observed in collaborative production and $R \& D$, which involves substantial coordination between firms. Use of IT may reduce such coordination cost or a firm, being capable in effective use of outside resources, tends to use IT intensively.

In order to further look into micro mechanism of IT and firm's performance, detail case studies should be supplemented to this statistical analysis. A question on complemental assets should 
involve various qualitative information on firm's capability and strategy, which cannot be addressed effectively with statistical analysis. In addition, due to the heterogeneity of IT use across sectors or across value chain of firm's activity, sector or application specific analysis works more effectively to analyze detail questions. A next step of this study is stepping into jungles, without loosing views from the sky.

\section{References}

Atrostic, B. K. and S. Nguyen (2002), Computer Networks and US Manufacturing Plant Productivity: New Evidence from CNUS Data, Center for Economic Studies Working Paper 02-01, January 2002

Bailiy, M. N (2002), The New Economy: Post Mortem or Second Wind? , Journal of Economic Perspectives, vol. 16, no. 2 pp. 3-22

Bartel and Lichtenberg (1987), The Comparative Advantage of Educated Workers in Implementing New Technologies, Review of Economics and Statistics, vol 69

Berndt, E. and J. Morrison (1995), High-tech Capital Formation and Economic Performance in U.S. Manufacturing Industries: An Explanatory Analysis, Journal of Econometrics, vol 65 pp9-43

Berndt, E., J. Morrison and Rosenblum (1992), High-tech Capital, Economic and Labor Composition in U.S. Manufacturing Industries: An Explanatory Analysis, NBER Working Paper \#4010

Bresnahan, T. (1997), Computerization and Wage Dispersion: An Analytical Reinterpretation, a paper presented at NBER Productivity Workshop, Cambridge USA, August 1997

Bresnahan T. , E. Brynjolfsson and L. M. Hitt (2002), Information Technology, Workplace Organization, and the Demand for Skilled Labor: Firm-Level Evidence, Quarterly Journal of Economics, Vol. 117, pp. 339-376

Bresnahan, T. and S. Greenstein (1997), Technical Progress and Co-invension in Computing and the Use of Computers, Brooking Paper on Economic Activities, Microeconomics pp. 1-77.

Bresnahan, T. and M. Trajtenberg (1995), General Purpose Technologies 'Engines of Growth?', Journal of Econometrics, vol 65 pp83-108

Brynjolfsson, E. and L. Hitt (1995), Information Technology as a Factor of Production: The Role of Differences Among Firms, Economics of Innovation and New Technology, 1995 vol. 3, pp183-199

Brynnolffson E., L. Hitt and S. Yang (2002), Intangible Assets: Computers and Organizational Capital, Brookings Paper on Economic Activities 1: 2002 
Brynjolfsson, Malone, Gurbaxani and Kambil (1994), An Empirical Analysis of the Relationship Between Information Technology and Firm Size, MIT Sloan School CCS Working Paper \#123

Gordon, R. (2000), Does the "New Economy" Measuring up to the Great Inventions of the Past?. forthcoming in the Journal of Economic Perspectives

Griliches, Z. (1992), Introduction, in Output Measurement in the Service Sector, Z. Griliches ed. University of Chicago Press

Griliches, Z. and J. Hausman (1984), Errors in Variable in Panel Data, Journal of Econometrics 31, 93-118

Griliches, Z. and J. Mairesse (1995), Production Functions: The Search for Identification, NBER Working Paper No. 5067

J orgenson, D. W. (2001), I nformation Technology and the US Economy, American Economic Review, Vol. 91, No. 1, March 2001.

Jorgenson, D. W. and K. Motohashi (2003), Economic Growth of Japan and the United States in the Information Age, RIETI Discussion Paper Series \#03-E-015, 2003/07

Krueger, A. (1993), How Computer Have Changed the Wage Structure? Evidence from Micro Data, Quarterly Journal of Economics, pp. 33-60

Lichtenberg, F. (1995), The Output Contributions of Computer Equipment and Personnel: A Firm Level Analysis, NBER Working Paper \#4540

Morrison, J. and E. Berndt (1991), Assessing the Productivity of Information Technology Equipment in U.S. Manufacturing Industries, NBER Working Paper \#3582

Motohashi, K. (2001), Economic Analysis of Information Network: Organizational and Productivity Impacts on Japanese Firms, MITI, Tokyo, Japan

Motohashi K. (1997), ICT Diffusion and its Economic Impacts on OECD countries, OECD Science, Technology and Industry Review, no. 20, OECD, Paris

Motohashi K. (1995), Firm Level Survey of Information Network in Japan, a paper presented for the OECD Economic Workshop of Information Infrastructure No.2, December 1995, Istanbul Turkey

Oliner, S. and D. Sichel (2000), The Resurgence of Growth in the Late 1990's: Is Information Technology the Story?" working paper, Federal Reserve Board, Feburary 2000

U.S. Bureau of Census (1993), The Survey of Manufacturing Technology: Factors Affecting Adoption; SMT/91-2, U.S. Government Printing Office, Washington DC, 1993

Woodridge (2002), Econometric Analysis of Cross Section and Panel Data, MIT Press 
Table 1: Breakdown of IT expenditure in 1999

\begin{tabular}{l|r|r}
\hline Hardware & & \\
\multicolumn{1}{|c|}{ Depreciation } & $6,650.6$ & $6.3 \%$ \\
$\quad$ Rental or lease expense & $20,467.7$ & $19.3 \%$ \\
$\quad$ Others & $7,732.5$ & $7.3 \%$ \\
\hline Software & $22,129.7$ & $20.9 \%$ \\
\hline Services & $17,424.3$ & $16.4 \%$ \\
\hline Communication Expense & $5,574.8$ & $5.3 \%$ \\
\hline IT labor compensation & $18,285.5$ & $17.2 \%$ \\
\hline Other expenses & $7,803.8$ & $7.4 \%$ \\
\hline \hline Total & $106,068.9$ & $100.0 \%$ \\
\hline
\end{tabular}

(Source: ICT Workplace Survey)

Table 2: Panel estimate of IT's contribution to value added

(Manufacturing)

\begin{tabular}{|c|c|c|c|c|c|c|c|c|}
\hline & \multicolumn{2}{|l|}{ TOTAL } & $\begin{array}{c}\text { BETWEE } \\
\text { coef }\end{array}$ & $\mathrm{V}$ t-value & $\begin{array}{c}\text { WITHIN } \\
\text { coef }\end{array}$ & t-value & $\begin{array}{c}\text { RANDOM } \\
\text { coef }\end{array}$ & t-value \\
\hline$\overline{\text { EMP }}$ & 0.704 & 169.340 & 0.697 & 94.860 & 0.535 & 54.680 & 0.715 & 141.090 \\
\hline CAP & 0.224 & 88.790 & 0.224 & 52.730 & 0.135 & 28.570 & 0.206 & 66.050 \\
\hline IT & 0.134 & 58.680 & 0.144 & 32.190 & 0.102 & 38.200 & 0.123 & 53.920 \\
\hline Hausı & & CHISQ(3 & 1258.78 & -value & {$[.0000]$} & & & \\
\hline
\end{tabular}

(Wholesale and Retial)

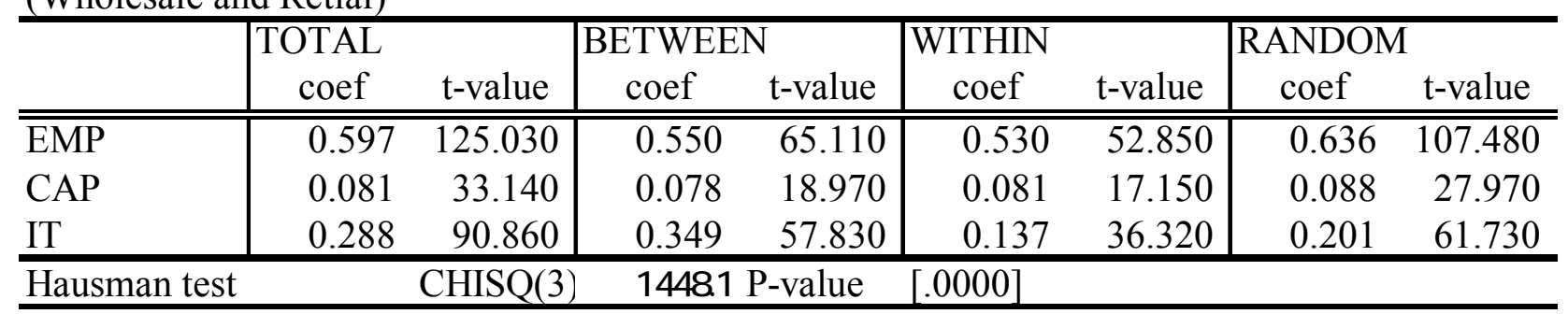

Table 3: Use of information network by year

\begin{tabular}{|c|c|c|c|c|}
\hline \multicolumn{3}{|c|}{ network use in } & \multirow[t]{2}{*}{ \# of firm } & \multirow[t]{2}{*}{$(\%)$} \\
\hline 91 & 94 & 97 & & \\
\hline 0 & 0 & 0 & 561 & 4.9 \\
\hline 0 & 0 & 1 & 401 & 3.5 \\
\hline 0 & 1 & 0 & 332 & 2.9 \\
\hline 0 & 1 & 1 & 626 & 5.5 \\
\hline 1 & 0 & 0 & 392 & 3.4 \\
\hline 1 & 0 & 1 & 541 & 4.8 \\
\hline 1 & 1 & 0 & 1331 & 11.7 \\
\hline 1 & 1 & 1 & 7185 & 63.2 \\
\hline & & & 11369 & 100 \\
\hline
\end{tabular}


Table 4: Changes in network adoption rate

\begin{tabular}{l|r|r|r|r}
\hline & \multicolumn{1}{|c|}{1991} & \multicolumn{1}{|c|}{1994} & \multicolumn{1}{c|}{1997} & \multicolumn{1}{c}{2000} \\
\hline \hline (Manufacturing) & & & & \\
intra firm network & $63.2 \%$ & $58.6 \%$ & $58.7 \%$ & $69.9 \%$ \\
inter firm network & $39.8 \%$ & $48.7 \%$ & $29.6 \%$ & $39.4 \%$ \\
open network & - & - & $3.2 \%$ & $6.3 \%$ \\
e- commerce & - & - & $0.9 \%$ & $19.9 \%$ \\
No network & $21.0 \%$ & $18.6 \%$ & $23.6 \%$ & $9.9 \%$ \\
\hline (Wholesale and Retail) & & & & \\
intra firm network & $70.2 \%$ & $62.5 \%$ & $57.1 \%$ & $68.3 \%$ \\
inter firm network & $52.2 \%$ & $57.1 \%$ & $32.6 \%$ & $42.8 \%$ \\
open network & - & - & $3.1 \%$ & $6.7 \%$ \\
e- commerce & - & - & $1.2 \%$ & $21.9 \%$ \\
No network & $13.1 \%$ & $11.2 \%$ & $21.1 \%$ & $9.8 \%$ \\
\hline
\end{tabular}

Table 5: TFP and network use

\begin{tabular}{|c|c|c|c|c|c|c|c|c|}
\hline & \multicolumn{4}{|c|}{ Manufacturing } & \multicolumn{4}{|c|}{ Wholesale and Retail } \\
\hline & Coef. & Std. & $\mathrm{t}$ & $P>t$ & Coef. & Std. & $\mathrm{t}$ & $P>t$ \\
\hline$\overline{N E T}=91, \mathrm{TFP}=91-94$ & & & & & & & & \\
\hline intra firm network & 0.010 & 0.009 & 1.00 & $32 \%$ & -0.006 & 0.013 & -0.43 & $67 \%$ \\
\hline inter firm network & 0.031 & 0.009 & 3.35 & $0 \%$ & -0.003 & 0.012 & -0.27 & $79 \%$ \\
\hline ordering & 0.005 & 0.009 & 0.56 & $58 \%$ & & & & \\
\hline production & 0.016 & 0.009 & 1.81 & $7 \%$ & & & & \\
\hline inventory & 0.005 & 0.009 & 0.55 & $59 \%$ & & & & \\
\hline logistics & 0.013 & 0.010 & 1.29 & $20 \%$ & & & & \\
\hline customer relation & - 0.001 & 0.012 & -0.12 & $91 \%$ & - 0.008 & 0.013 & -0.66 & $51 \%$ \\
\hline accounting & 0.001 & 0.009 & 0.06 & $95 \%$ & 0.004 & 0.012 & 0.36 & $72 \%$ \\
\hline human resource & 0.002 & 0.012 & 0.19 & $85 \%$ & -0.009 & 0.016 & -0.55 & $58 \%$ \\
\hline management planning & 0.010 & 0.009 & 1.05 & $29 \%$ & -0.009 & 0.012 & -0.71 & $48 \%$ \\
\hline $\mathrm{NET}=94, \mathrm{TFP}=94-97$ & & & & & & & & \\
\hline intra firm network & 0.001 & 0.008 & 0.10 & $92 \%$ & 0.037 & 0.010 & 3.69 & $0 \%$ \\
\hline inter firm network & 0.007 & 0.008 & 0.85 & $40 \%$ & 0.021 & 0.010 & 2.08 & $4 \%$ \\
\hline ordering & 0.020 & 0.008 & 2.44 & $2 \%$ & & & & \\
\hline production & 0.007 & 0.008 & 0.85 & $40 \%$ & & & & \\
\hline inventory & 0.011 & 0.008 & 1.36 & $17 \%$ & & & & \\
\hline logistics & 0.008 & 0.010 & 0.80 & $43 \%$ & & & & \\
\hline customer relation & 0.011 & 0.013 & 0.87 & $38 \%$ & 0.013 & 0.011 & 1.13 & $26 \%$ \\
\hline accounting & 0.010 & 0.009 & 1.10 & $27 \%$ & 0.023 & 0.011 & 2.20 & $3 \%$ \\
\hline human resource & 0.020 & 0.013 & 1.60 & $11 \%$ & 0.056 & 0.016 & 3.55 & $0 \%$ \\
\hline management planning & -0.003 & 0.029 & -0.09 & $93 \%$ & 0.048 & 0.033 & 1.45 & $15 \%$ \\
\hline $\mathrm{NET}=97, \mathrm{TFP}=97-00$ & & & & & & & & \\
\hline intra firm network & 0.022 & 0.014 & 1.64 & $10 \%$ & 0.043 & 0.015 & 2.90 & $0 \%$ \\
\hline inter firm network & 0.018 & 0.013 & 1.39 & $16 \%$ & 0.005 & 0.010 & 0.54 & $59 \%$ \\
\hline open network & -0.030 & 0.029 & -1.06 & $29 \%$ & - 0.013 & 0.013 & -1.03 & $31 \%$ \\
\hline pos/eos & & & & & 0.020 & 0.015 & 1.31 & $19 \%$ \\
\hline cad/cam & 0.019 & 0.015 & 1.25 & $21 \%$ & & & & \\
\hline EDI & 0.036 & 0.016 & 2.27 & $2 \%$ & 0.035 & 0.018 & 2.00 & $5 \%$ \\
\hline e- commerce & -0.048 & 0.050 & -0.96 & $34 \%$ & 0.002 & 0.053 & 0.03 & $97 \%$ \\
\hline
\end{tabular}


Table 6-a : Productivity, network use and inter firms collaborative activities (net, out in 1991, productivity growth: 1991-94)

\begin{tabular}{|c|c|c|c|c|c|c|c|c|c|c|}
\hline & $(1)$ & (2) & (3) & $(4)$ & (5) & (6) & $(7)$ & (8) & (9) & $(10)$ \\
\hline inter firms network & $\begin{array}{c}0.029 \\
(0 \%)\end{array}$ & & & $\begin{array}{l}0.018 \\
(23 \%)\end{array}$ & & & $\begin{array}{r}0.027 \\
(0 \%)\end{array}$ & & & $\begin{array}{c}0.025 \\
(1 \%)\end{array}$ \\
\hline outsourcing & & $\begin{array}{l}0.007 \\
(50 \%) \\
\end{array}$ & & $\begin{array}{r}-0.003 \\
(82 \%)\end{array}$ & & & & & & \\
\hline net*outsourcing & & & $\begin{array}{c}0.030 \\
(0 \%)\end{array}$ & $\begin{array}{l}0.016 \\
(37 \%) \\
\end{array}$ & & & & & & \\
\hline co- production & & & & & $\begin{array}{l}0.030 \\
(20 \%) \\
\end{array}$ & & $\begin{array}{l}0.008 \\
(82 \%) \\
\end{array}$ & & & \\
\hline net*coproduction & & & & & & $\begin{array}{c}0.061 \\
(6 \%)\end{array}$ & $\begin{array}{r}0.038 \\
(43 \%) \\
\end{array}$ & & & \\
\hline co- R\&D & & & & & & & & $\begin{array}{c}0.025 \\
(5 \%)\end{array}$ & & $\begin{array}{l}0.015 \\
(42 \%) \\
\end{array}$ \\
\hline net*co- R\&D & & & & & & & & & $\begin{array}{c}0.039 \\
(1 \%)\end{array}$ & $\begin{array}{l}0.010 \\
(68 \%)\end{array}$ \\
\hline
\end{tabular}

\begin{tabular}{|c|c|c|c|c|c|c|c|c|c|c|}
\hline & (1) & (2) & (3) & (4) & (5) & (6) & $(7)$ & (8) & (9) & (10) \\
\hline network for production & $\begin{array}{l}0.015 \\
(10 \%) \\
\end{array}$ & & & $\begin{array}{r}-0.018 \\
(21 \%) \\
\end{array}$ & & & $\begin{array}{c}0.016 \\
(8 \%) \\
\end{array}$ & & & $\begin{array}{l}0.011 \\
(27 \%) \\
\end{array}$ \\
\hline outsourcing & & $\begin{array}{l}0.007 \\
(50 \%)\end{array}$ & & $\begin{array}{c}-0.024 \\
(9 \%)\end{array}$ & & & & & & \\
\hline net- prod*outsourcing & & & $\begin{array}{r}0.027 \\
(0 \%) \\
\end{array}$ & $\begin{array}{c}0.052 \\
(0 \%)\end{array}$ & & & & & & \\
\hline co- production & & & & & $\begin{array}{l}0.030 \\
(20 \%) \\
\end{array}$ & & $\begin{array}{r}0.062 \\
(13 \%) \\
\end{array}$ & & & \\
\hline net- prod*coproduction & & & & & & $\begin{array}{l}0.018 \\
(54 \%) \\
\end{array}$ & $\begin{array}{c}-0.050 \\
(32 \%)\end{array}$ & & & \\
\hline co- R\&D & & & & & & & & $\begin{array}{c}0.025 \\
(5 \%)\end{array}$ & & $\begin{array}{l}0.009 \\
(68 \%)\end{array}$ \\
\hline net- prod*co- R\&D & & & & & & & & & $\begin{array}{c}0.032 \\
(2 \%)\end{array}$ & $\begin{array}{l}0.019 \\
(49 \%)\end{array}$ \\
\hline
\end{tabular}


Table 6-b : Productivity, network use and inter firms collaborative activities (net, out in 1994, productivity growth:1994-97)

\begin{tabular}{l||c|c|c|c||c|c|c}
\hline & $(1)$ & $(2)$ & $(3)$ & $(4)$ & $(5)$ & $(6)$ & $(7)$ \\
\hline \hline Inter firms network & 0.006 & & & 0.004 & & & \\
& $(43 \%$ & & & $(80 \%)$ & & & \\
\hline outsourcing & & 0.015 & & 0.013 & & & \\
& & $(12 \%)$ & & $(31 \%)$ & & & \\
\hline net*outsourcing & & & 0.011 & 0.003 & & & \\
\hline Network for production & & & & & 0.011 & & -0.003 \\
& & & & & $(18 \%)$ & & $(83 \%)$ \\
\hline outsourcing & & & & & & & 0.005 \\
& & & & & & & $(67 \%)$ \\
\hline net- prod*outsourcing & & & & & & 0.018 & 0.018 \\
& & & & & & $(4 \%)$ & $(31 \%)$ \\
\hline
\end{tabular}


Table 6-c : Productivity, network use and inter firms collaborative activities (1994-97)

\begin{tabular}{|c|c|c|c|c|c|c|c|c|c|c|}
\hline & (1) & (2) & (3) & (4) & (5) & (6) & $(7)$ & (8) & (9) & $(10)$ \\
\hline inter firms network & $\begin{array}{l}0.021 \\
(12 \%) \\
\end{array}$ & & & $\begin{array}{r}0.047 \\
(4 \%) \\
\end{array}$ & & & $\begin{array}{l}0.019 \\
(16 \%) \\
\end{array}$ & & & $\begin{array}{l}0.020 \\
(16 \%) \\
\end{array}$ \\
\hline outsourcing & & $\begin{array}{l}0.014 \\
(42 \%) \\
\end{array}$ & & $\begin{array}{l}0.024 \\
(21 \%) \\
\end{array}$ & & & & & & \\
\hline net*outsourcing & & & $\begin{array}{l}0.010 \\
(56 \%) \\
\end{array}$ & $\begin{array}{r}-0.044 \\
(15 \%) \\
\end{array}$ & & & & & & \\
\hline co- production & & & & & $\begin{array}{r}-0.009 \\
(86 \%)\end{array}$ & & $\begin{array}{r}-0.048 \\
(45 \%)\end{array}$ & & & \\
\hline net*coproduction & & & & & & $\begin{array}{r}0.054 \\
(42 \%) \\
\end{array}$ & $\begin{array}{r}0.080 \\
(35 \%) \\
\end{array}$ & & & \\
\hline co- R\&D & & & & & & & & $\begin{array}{r}0.006 \\
(82 \%) \\
\end{array}$ & & $\begin{array}{l}0.001 \\
(98 \%) \\
\end{array}$ \\
\hline net*co- R\&D & & & & & & & & & $\begin{array}{l}0.023 \\
(52 \%) \\
\end{array}$ & $\begin{array}{l}0.008 \\
(87 \%) \\
\end{array}$ \\
\hline & $(1)$ & (2) & (3) & $(4)$ & (5) & (6) & $(7)$ & (8) & (9) & $(10)$ \\
\hline EDI & $\begin{array}{r}0.055 \\
(0 \%) \\
\end{array}$ & & & $\begin{array}{c}0.073 \\
(9 \%) \\
\end{array}$ & & & $\begin{array}{c}0.054 \\
(0 \%) \\
\end{array}$ & & & $\begin{array}{c}0.059 \\
(0 \%) \\
\end{array}$ \\
\hline outsourcing & & $\begin{array}{l}0.014 \\
(42 \%) \\
\end{array}$ & & $\begin{array}{l}0.013 \\
(50 \%) \\
\end{array}$ & & & & & & \\
\hline EDI*outsourcing & & & $\begin{array}{c}0.050 \\
(1 \%) \\
\end{array}$ & $\begin{array}{r}-0.023 \\
(62 \%) \\
\end{array}$ & & & & & & \\
\hline co- production & & & & & $\begin{array}{r}-0.009 \\
(86 \%)\end{array}$ & & $\begin{array}{r}-0.035 \\
(57 \%)\end{array}$ & & & \\
\hline EDI*coproduction & & & & & & $\begin{array}{l}0.066 \\
(45 \%) \\
\end{array}$ & $\begin{array}{r}0.058 \\
(59 \%) \\
\end{array}$ & & & \\
\hline Co- R\&D & & & & & & & & $\begin{array}{l}0.006 \\
(82 \%) \\
\end{array}$ & & $\begin{array}{r}0.012 \\
(70 \%) \\
\end{array}$ \\
\hline EDI*co- R\&D & & & & & & & & & $\begin{array}{l}0.019 \\
(68 \%) \\
\end{array}$ & $\begin{array}{r}-0.040 \\
(49 \%) \\
\end{array}$ \\
\hline
\end{tabular}


Figure 1: Changes in IT capital's output elasticity
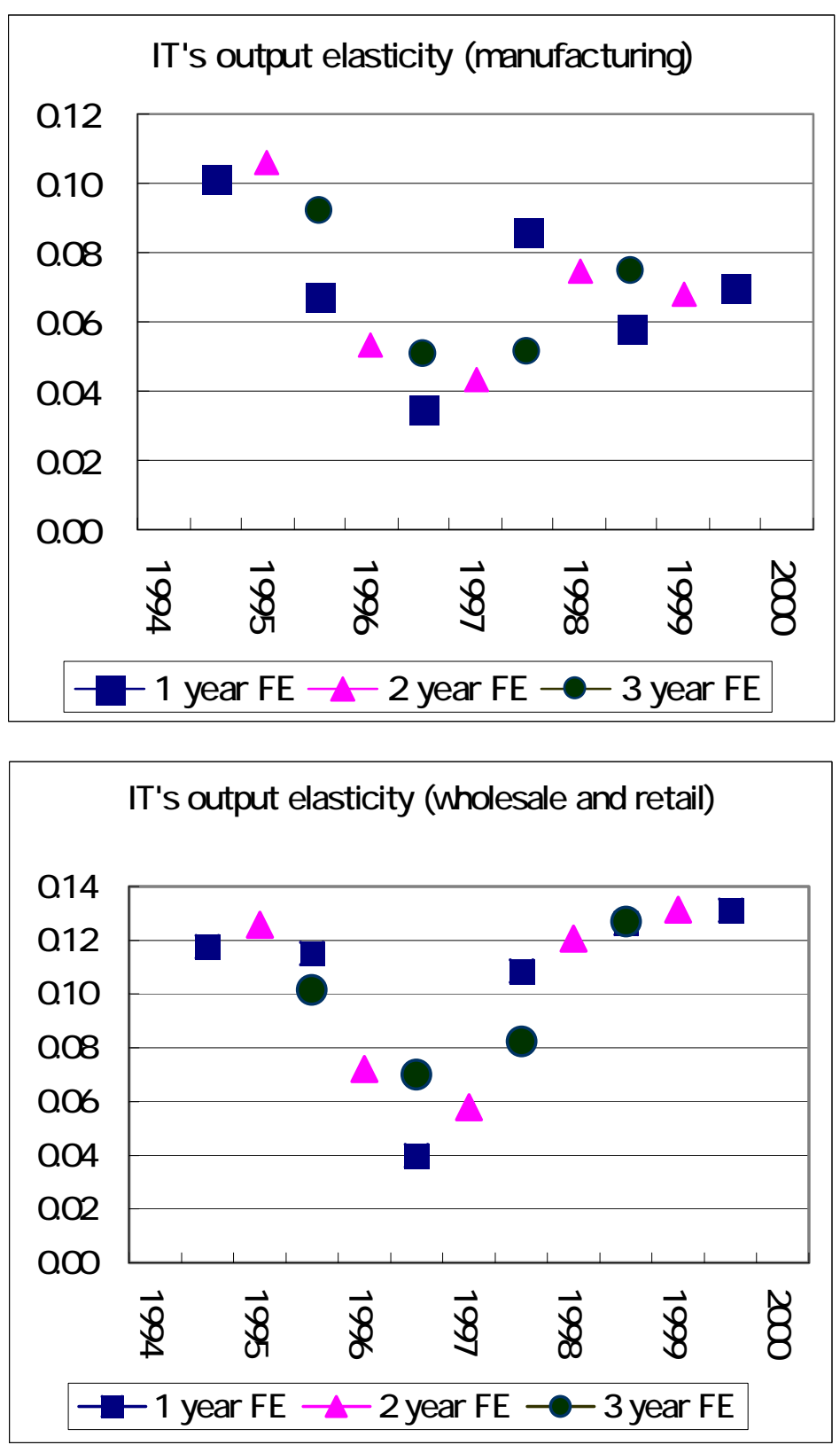
Figure 2: Labor Productivity and network use

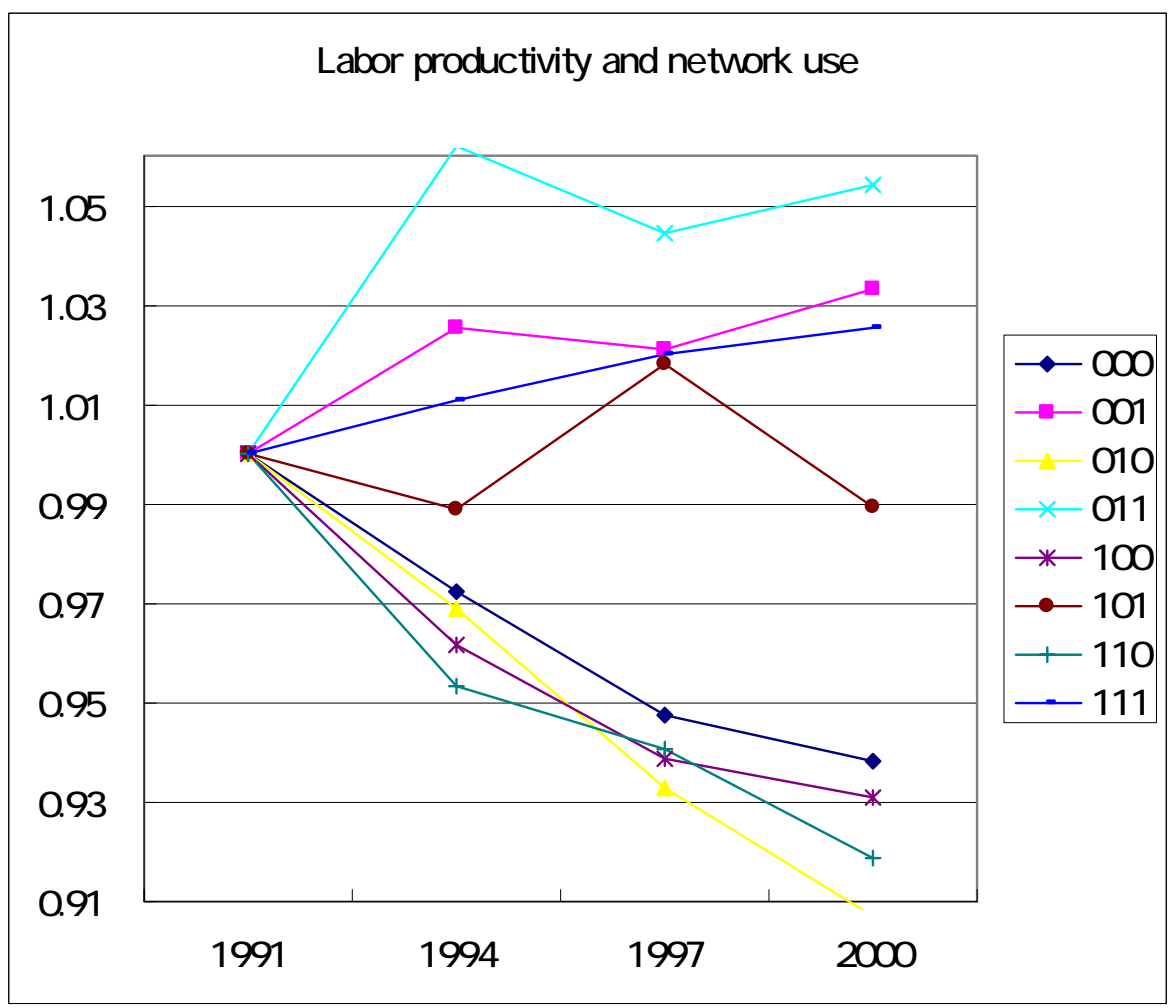

Figure 3: Employment and network use

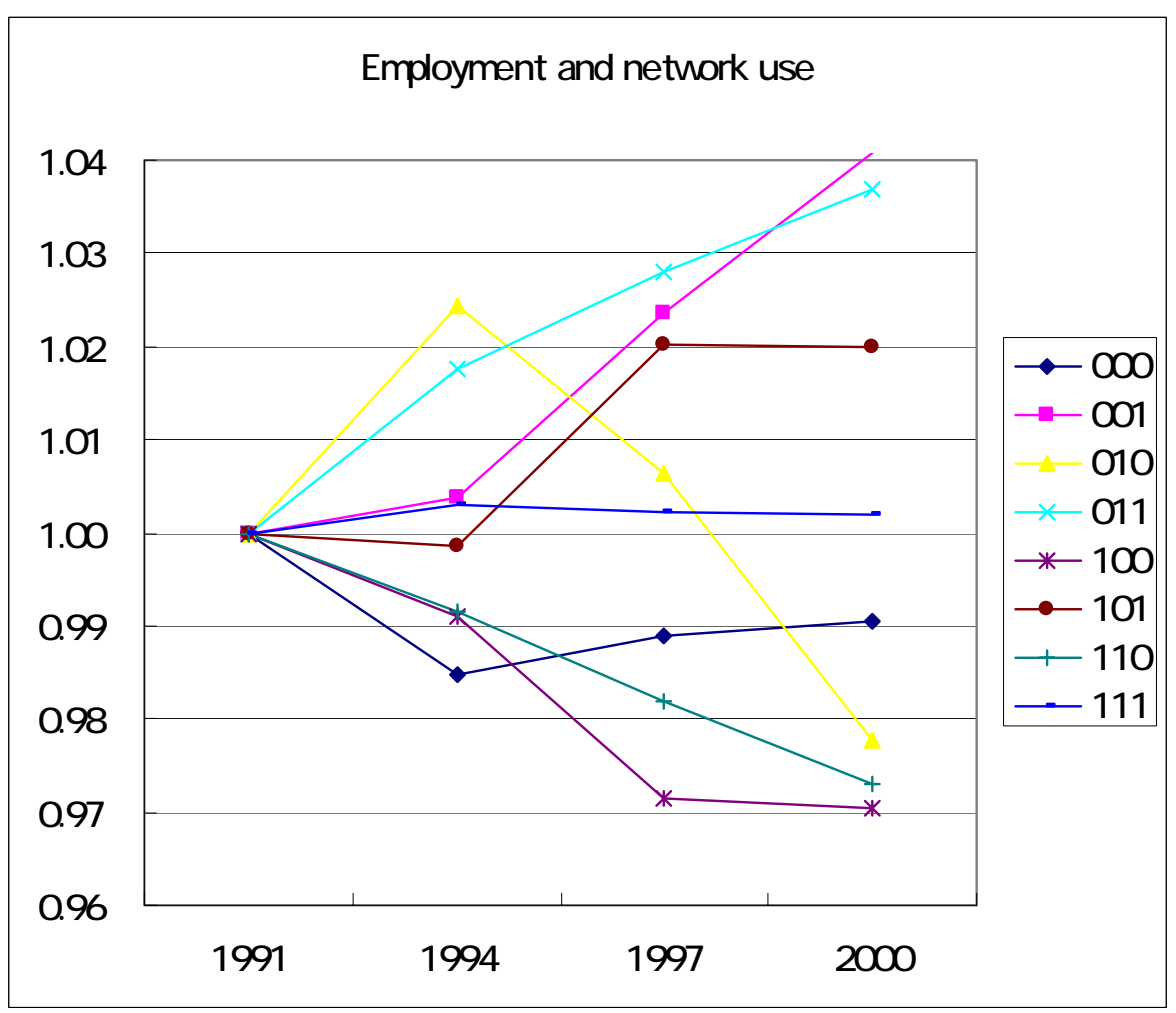

